\title{
EMPOWERMENT THROUGH EDUCATION: THE CONTRIBUTIONS OF CHAVARA KURIAKOSE ELIAS
}

\section{DR. DEEPA ROSELIN JOSEPH}

Assistant Professor, Thomas College, Pazhavangady P.O, Ranni, Kerala, India

\begin{abstract}
St. Chavara Kuriakose Elias, a luminary among the topmost social reformers of India, was the leader of Syrian Catholics in Kerala, India. He can be considered as the morning star of social reformers, and he was such great revolutionary who came before the time. The general trend of stagnation during his time was surpassed by his luminous vision, vibrant actions and educational and literary assignments. Along with the duty as a priest in the church, he could render a great service to the general public of Kerala irrespective of caste, creed and colour. The Catholic Church raised him to the status of a saint on $23^{\text {rd }}$ Nov 2014. This study aims at describing the contributions of Chavara in the educational upliftment of his fellowmen, in a caste ridden society, where their conditions were deplorable.
\end{abstract}

KEYWORDS: Downtrodden, Education, Empowerment, Society \& Women

Received: May 09, 2020; Accepted: May 29, 2020; Published: Aug 04, 2020; Paper Id.: IJHRDEC20202

\section{INTRODUCTION}

The British and Indian administrators, who were actuated by liberal impulses introduced even in the early decades of the $19^{\text {th }}$ century, a series of administrative and social reforms with a view to modernize the administration and society of Kerala. By the $19^{\text {th }}$ century, Kerala witnessed a new era of peace and progress, which resulted in a renaissance of its own. The progress of social change in Kerala society during the 19th century has been interpreted as the output of the interplay of several internal and external factors like introduction of Western education, work of Christian missionaries and the progressive works done by the rulers of that time.

The role played by Saint Kuriakose Elias Chavara (1805-1971), a spiritual colossal figure in this regard cannot be confined into a water tight compartment. Saint Chavara was a radical and total transformer, not merely a saint confined to the Church and the Christian community, but who shed light and paved new paths for the wider humanity in general. He was an integral transformer, who contributed immensely to the overall growth of the $19^{\text {th }}$ century Kerala. He is remembered for his various contributions to the socio-cultural development of Kerala. He was endowed with exceptional creative and leadership qualities.

\section{OBJECTIVES AND METHODOLOGY}

The general objective is to identify the role played by Chavara Kuriakose Elias for the empowerment of Kerala society, using education as the medium. The specific objectives are

- To identify the status of Kerala society in the $18^{\text {th }}$ and $19^{\text {th }}$ centuries.

- To analyze the socio economic status of the marginalized sessions in Kerala, during the $19^{\text {th }}$ century 
- To describe the revolutionary measures adopted by Chavara in the field of education, and thereby reforming the society.

This is a historical study based on secondary sources. Complete works of Chavara (CWC) in four Volumes, and other secondary sources gathered on his life have been examined and the results are presented.

\section{KERALA SOCIETY IN THE EARLY $19^{\text {th }}$ CENTURY}

Kerala's achievements in the field of education - near total literacy, free and universal primary education, low dropout rate at the school level, easy access to educational institutions, gender equality etc. are well known. She had a long and definite lead in the history of education among the Indian States, and stands miles ahead among the other Indian states in social indicators like literacy rate, higher enrolment of students, higher percentage of girls and SC and ST students in schools, low dropout rate among students etc. This unique position, which Kerala has achieved, is not the result of a sudden spurt of activity in the field of education in recent times, but the climax and culmination of the enlightened policies followed by its rulers from the very early days and the intellectual pursuits of the people spread over several centuries.

In the eighteenth and nineteenth centuries, Kerala was in the stranglehold of the caste system. Its chief characteristic was the deep chasm, which separated the high castes from the lower castes. Polarized thinking along the lines of caste and creed was very much the norm. Each caste presumed itself to be superior and maintained a distance from every other. Politically in spite of the centralization of authority in the hands of the kings in Travancore and Cochin and the assumption of direct administration by the English East India Company in Malabar, the upper castes like the Brahmins, the Kshatriyas and the Nairs continued to enjoy several privileges and immunities. Economically, these high castes were the largest land owning classes and occupation too, was determined on the basis of caste. Socially too, the caste held its sway. Large sections of people had no access to education. Interdining or intermingling was not allowed. The evil customs of untouchability, unapproachability, unseeability played havoc on those days and lower castes were not allowed to walk in public places.

Kerala women, at that time were very much bound by the rules and customs of society. It was definitely a patriarchal society, and women had no freedom either at home or in the society or in the church. Early marriage, devoid of rights to family property, evils existed in the social customs like caste system, marumakkathayam, devadasi system, sambahdam made the life of women miserable. The condition of lower castes was not much different. They were denied social freedom education, property rights and lived in the property of land lords and worked for them as bonded laboureres. Human dignity was on cross roads and the inhuman practices earned her the name 'lunatic asylum'.

It was in this backdrop that, the role played by Chavara Kuriakose Elias in the social reform movement has to be remembered. A luminary among the topmost social reformers of India, he can be considered as the morning star of social reformers, and he was such a great revolutionary who came before the time.

\section{CONTRIBUTIONS OF CHAVARA TO EDUCATION}

Chavara identified that all sorts of discriminations are the result of ignorance, and so it must be wiped out. Identifying that, the means through which ignorance can be wiped out is by education; he set aside with the idea of imparting literacy to our people. In a society, in which, people were divided into several castes, he longed for social equality and social dignity. He firmly believed that education can bring social change, mobility and social development. Here we can note the vision of 
Chavara, a great vision of considering all as reflections of God. He saw in each human being, the God himself. So his vision of education was of an egalitarian nature-education for all, irrespective of caste, creed, religion, sex or anything else. He aimed to achieve this social development through multi faceted tasks-establishing schools, printing books, emanating the role of a teacher and innovator and equally through charitable activities. His educational idea was of an all inclusive nature with a secular character.

He started his work with the upliftment of his own community, Catholics. At that time, due to the schism that took place in Kerala Church, Catholics were denied education in Protestant institutions. As English education of Protestant missionaries were denied to Catholics, he realized that the community would remain subjugated if they did not move with the times. His creative mind found Sanskrit as the substitute and in the year 1846, Chavara established a Sanskrit school at a place called Mannanam. Here, his egalitarian vision came forward and in that institution, students from any caste or religion sat together and studied. Chavara was the first Indian, who not only dared to admit the untouchables to schools but also provided them with Sanskrit education, which was forbidden to the lower castes, thereby challenging social bans based on caste, as early as the former part of the $19^{\text {th }}$ century. Soon, he established some other schools in the nearby areas, and all these were silver stars that spread light in the inner souls of the marginalized sections of the society.

One of the root causes for the tremendous growth of education in Kerala can be traced back to a circular of Archbishop Bernadinos, that Chavara got issued. His revolutionary proposal to have an educational institution attached to every church was implemented and this pallikoodam movement became the Magna Carta for a revolutionary paradigm shift in the socio-cultural development of Kerala. Those schools became the incubators of a general public in Kerala society irrespective of caste and creed. The people of different religions and castes realized when they joined together in the same class that, they have something common and they are human beings having same flesh and blood.

It was in the first decade of the 21 st century that, on the orders of the Supreme Court, the government introduced a mid-day meal scheme in government schools. One and a half century before this, Fr Chavara provided food to students from poor families, because he believed that good food was a must for the intellectual and physical growth of children. Also, he knew that since children themselves were the bread winners of their houses, they could not afford a mid day meal for them. With the help of generous persons and also from the land, he bought near Mannanam for the purpose he met with the expenses.

Chavara was well aware of the potentials of women and visualized fact that women must also be educated. Sanctity and stability of the families mainly depended on well trained and educated women, who can make correct decisions. But at that time, the women were an extremely unprivileged group, suffered a lot religiously, socially, and economically. They were largely deprived of the basic rights of education, property inheritance and were not able to move freely in society. He realized the role of education in women empowerment and advocated measures for its implementation. The empowerment measures began in the Catholic community, where a religious Congregation of women was set up (CMC Congregation) with a social mission and through it education of girls became more accessible.

Foreseeing the need of print media and literature to continue progress in educational, Chavara made his efforts to start a printing press, which was not an easy task at that time. So, he walked ahead of the times for the dissemination of knowledge. He started his efforts to hand over the intellectual acumen to generations, when there were no manufacturing of printing equipments in India. He made models of what he had seen, and got some local carpenters to fabricate one working model. It was not a mere model, while it was a wooden press and it worked. Thus, it became the third press in Travancore, 
and the first one to be set up under private ownership in the country in 1846. Chavara has proved his interest in printing press and publication, by situating press with great pain and struggle to awakening the Kerala church, especially in the field of literatures and devotional prayer books. Many people, especially young men and women were acquired knowledge on their mother tongue and various news about Kerala church, and news from other prominent areas. From this printing press, came the oldest existing Malayalam newspaper in circulation Nasrani Deepika.

Chavara is considered as the Apostle of Christian Literature in his time. A versatile linguist, who is well versed in several languages like Malayalam, Sanskrit, Latin, Tamil and Syriac, Chavara, devoted his time and energy to compose several literary works, both in prose and verse. His contributions are of two categories-literary (poetic) writings and spiritual writings. It is estimated that about one hundred and one writings (including all categories) of different languages have come to us. The writings include chronicles or historical works, spiritual writings, letters, writings related to administration etc. Chief among them were Atmanuthamam (The lamentations of a repentant Soul- a poem), Maranaveettil Paduvanulla Pana (A poem to sing in the bereaved house), Anasthaciayude Rakthasakshyam (The martyrdom of Anastacia), historical notes as Nalagamangal (Chronicles), Dhyana Sallapangal (Colloquies in meditation).

\section{CONCLUSIONS}

Today, Kerala with prolonged high literacy rate, high sex ratio is a State with high Human Development Index and Gender development Index. This exemplary achievement was not a single day-night activity. Several organizations, governments and well wishers put their heads and hands together to achieve this goal. Among them, the name of Chavara Kuriakose Elias plays a crucial role.

Beginning with his community, he with his far sightedness firmly believed that a society could make progress only through knowledge and wisdom. He considered education as the central factor for any basic development. Chavara acted as a catalyst for social change, not only to his community but his vision is evident in his interventions in the field of women and downtrodden too.

He understood the fact that dignity and culture of a society can be detected from the status of women in that society. Empowerment of women leads to benefit not only to the individual woman and to women groups, but also to the families and community as a whole through collective action for development.

Chavara played an important role in diminishing the caste consciousness among the people of Kerala, through admission of children even from lower classes and castes, in those days of severe caste restrictions. He initiated the task of assimilating the so-called untouchables to the mainstream society. With the spread of education, untouchability, unapproachability and other accompanying evils of a caste-ridden society faded into insignificance. The starting of boarding houses, hostels and orphanages in the centers of the CMI Congregation was a means to uplift the marginalized and economically weaker sections of the society. This helped them to come out of their traditional barriers, and became capable enough to play their roles in the revolutionary paradigm shift in the socio-cultural development of Kerala.

His initiatives are still continuing through his Congregations and also through the educationalists of then and now.

\section{REFERENCES}

1. Robin Jeffrey, Politics, Women and Well-being: How Kerala became a Model

2. New Delhi: Macmillan, 1993 
3. Menon, Sreedhara, A, Cultural Heritage of Kerala, An Introduction, Cochin: East West Publications Pvt. Ltd., 1978

4. Joseph Kanjiranthingai, The Pastoral vision of Kuriakose Elias Chavara, Bangalore, 1986,

5. K.S. Radhakrishnan, 'Chavarayachan Pothu Samooha Sratavaya Navoothana Nayakan', in PothuVldhyabyasam: Prasakthiyum Preshnangalum (Mal.), Roby Kannchira, (ed.), Kochi, 2011

6. GILL, MUKTI. "EMPOWERING QUALITY HIGHER EDUCATION USING INFORMATION TECHNOLOGY." International Journal of Educational Science and Research (IJESR) 4. 6, Dec 2014, 9-14

7. Suma Rose, Polity, Society, and women: with special reference to Travancore, 1700-1900 A.D, Carmel International Publishers House, 2004,

8. R.J.Hepzi Joy, "History and development of education of women in Kerala", Seminary publications, Thiruvanandapuram, 1995.

9. Singh, D. V., and ANUPAMA SAMAL. "Impact of Nutrition Education on Knowledge of Tribal Women." International Journal of Food Science \& Technology (IJFST) 6.4 (2016): 1-6.

10. Sushama Sahay, "Women and Empowerment- Approach and Strategies", Discovery Publishing House, Delhi, 1998.

11. Srinivasa Rao, A. B., P. M. Kumar, and P. S. Aithal. "Strategic Planning in Higher Education Institutions: A Case Study of SIMS-VISION 2025." International Journal of Educational Science and Research (IJESR) ISSN (P) (2015): 2249-6947.

12. Manjula Scaria, Binoy Joseph, The Legacy of Kuriakose Elias Chavara as a Social Reformer, International Journal of Scientific and Research Publications, Vol 5, Issue 7, July 2015.

13. Sumadsad, Concepcion, and Ariel Tuazon. "Gender and Development (GAD) Awareness in a Higher Education Institution." International Journal of Educational Science and Research (IJESR) 6.3 (2016).

14. Mollykutty P.V, Kennedy Andrew Thomas, St. Kuriakose Elias Chavara: A Unique and Vibrant Educational Visionary of Kerala, International Journal of Social Science and Humanities Research Vol 3, Issue 2, June 2015. 

